\title{
ADAPTATION OF STAFF OF BUSINESS STRUCTURES: ESSENCE AND COMPONENTS
}

\section{АДАПТАЦІЯ ПЕРСОНАЛУ ПІДПРИЕМНИЦЬКИХ СТРУКТУР: СУТНІСТЬ ТА СКЛАДНИКИ}

\author{
Valentyna V. Smachylo \\ miroslava.valya@ukr.net \\ ORCID 0000-0002-6153-1564 \\ Taras L. Nalyvaiko \\ miroslava.valya@gmail.com \\ ORCID 0000-0003-2149-7370 \\ Pavlo A. Riznyk \\ ORCID 000-0003-1080-4275
}

\author{
В. В. Смачило \\ канд. екон. наук, доцент
}

\section{Т. Л. Наливайко}

аспірант

П. А. Різник
магістр

\section{Харківський національний університет будівнццтва та архітектури, м. Харків Kharkiv National University of Civil Engineering and Architecture, Kharkiv}

\begin{abstract}
Purpose. Identification of the category of "personnel adaptation" through the disclosure and substantiation of the essential load of its components.

Method. The study used: morphological and structural-logical analyzes, which made it possible to establish the essence of the components of the "personnel adaptation" category; graphic and tabular methods, which allowed to structure and summarize information, as well as present the results; logical generalization method - to form conclusions.

Results. The study analyzed, identified and delineated categories that describe the adaptation of an employee in the enterprise "industrial adaptation", "non-production adaptation", "labor adaptation" and "personnel adaptation". It is determined that the use of the term "production adaptation" is limited and evolutionarily inappropriate in the current economic conditions, so it is more fair to distinguish adaptation that is directly related to the conduct of labor (labor adaptation), and adaptation that is not directly related to the conduct of labor ( non-labor adaptation) within the personnel adaptation. It is determined that the essence of personnel adaptation is expedient to reveal through the selection of individual components (according to the meaningful classification feature), which include: professional; psychophysiological; socio-psychological, organizational; economic and cultural and everyday life. Accordingly, the author redefines the nature of these types of adaptation.

Scientific novelty. The structuring of the "staff adaptation" category has been improved by specifying the components and their essence, which, unlike the existing ones, is based on the principle of direct or indirect participation in the labor activity of employees.

Practical importance. Substantiation of the theoretical basis of adaptation of the personnel of the entrepreneurial structures is the basis for the correct implementation of the methodological toolkit of adaptation of employees, which directly affects the efficiency of the enterprise.
\end{abstract}

Key words: adaptation; labor adaptation; non-labor adaptation; staff adaptation.

Анотація. Мета. Ідентифікація категорії «адаптація персоналу» через розкриття та обгрунтування сутнісного навантаження іiі компонент.

Методика. У дослідженні використано: морфологічний та структурно-логічний аналізи, які дали змогу встановити сутнісне навантаження складників категорії «адаптація персоналу»; графічний та табличний методи, що дало змогу структурувати та узагальнити інформацію, а також презентувати результати; метод логічних узагальнень - для формування висновків.

Результати. У дослідженні було проаналізовано, ідентифіковано та розмежовано категорії, які описують адаптацію працівника на підприємстві: «виробнича адаптація», «невиробнича адаптація», «трудова адаптація» та «адаптація персоналу». Визначено, що використання терміна «виробнича адаптація» має обмежений і еволюційно недоцільний характер у сучасних умовах господарювання, тому більш справедливим є виділення в межах адаптації персоналу адаптації, яка безпосередньо пов'язана із веденням трудової діяльності (трудова адаптація), та адаптації, яка безпосередньо не пов’язана із веденням трудової діяльності (позатрудова адаптація). 
Визначено, що сутнісне навантаження адаптації персоналу доцільно розкривати через виділення окремих компонент (видів адаптації персоналу за змістовою класифікаційною ознакою), до яких зараховано професійну, психофізіологічну, соціально-психологічну, організаційну, економічну та культурно-побутову. Відповідно, надано авторське переосмислення сутності вказаних видів адаптації.

Наукова новизна. Вдосконалено структуризацію категорії «адаптація персоналу» шляхом уточнення складників та їх сутності, яка, на відміну від наявних, базується на принципі безпосередньої чи опосередкованої участі в трудовій діяльності працівників

Практична значущість. Обгрунтування теоретичного базису адаптації персоналу підприємницьких структур $€$ основою для коректної імплементації методичного інструментарію адаптації працівників, що безпосередньо впливає на ефективність діяльності підприємства.

Ключові слова: адаптація; трудова адаптація; позатрудова адаптація; адаптація персоналу.

\section{ПОСТАНОВКА ПРОБЛЕМИ}

Сучасні умови господарювання демонструють зростаючу роль людини в економічному розвитку на будьякому рівні соціально-економічної системи, відповідно, утримання кадрового потенціалу на підприємстві є запорукою його економічного зростання. Досить важко уявити сталий розвиток підприємницьких структур без оновлення та розширення кадрового складу. Наявна у вітчизняній економіці ситуація демонструє негативну тенденцію відтоку працівників за кордон, що провокує кадровий дефіцит та примушує керівництво підприємств переглядати внутрішні управлінські процеси, в тому числі й процеси адаптації персоналу. За даними [18], адаптація може виступати як конкурентна перевага, впливаючи на плинність кадрів (зменшення на 10-20\% [26]) та пришвидшуючи вихід на оптимальний рівень продуктивності нових працівників [27]. Саме тому дослідження понятійно-категоріального апарату адаптації персоналу підприємницьких структур є необхідною умовою розуміння сутності цього процесу, його складників та, відповідно, потребує актуалізації в динамічних умовах сьогодення.

\section{АНАЛІЗ ОСТАННІХ ДОСЛІДЖЕНЬ І ПУБЛІКАЦІЙ}

Питання адаптації персоналу, трудової та виробничої адаптацій не є новим у науково-практичних дослідженнях, але не втрачає своєї актуальності і нині, бо трансформації вимагають переосмислення ролі та наповнення адаптаційного процесу стосовно персоналу як науковцями, так і керівниками суб'єктів господарювання.

Це питання висвітлюється в закордонній $[4 ; 10$; $23]$ та вітчизняній $[9 ; 14 ; 27]$ навчальній літературі, наукових публікаціях українських $[8 ; 27 ; 28]$ та закордонних вчених [26]. Розглядаються сутність та структура адаптації працівників, методичний інструментарій іiі забезпечення на підприємствах, який постійно удосконалюється та змінюється відповідно до запитів працівників.

\section{ВІДОКРЕМЛЕННЯ НЕ ВИРІШЕНИХ РАНІШЕ ЧАСТИН ЗАГАЛЬНОӤ ПРОБЛЕМИ}

Водночас внаслідок динамічних трансформацій соціально-економічних систем невирішеним питан- ням $є$ ідентифікація сутнісного наванатження адаптацій персоналу та їі складників.

Мета дослідження - ідентифікація категорії «адаптація персоналу» через розкриття та обгрунтування сутнісного навантаження іiі компонент.

\section{ОСНОВНИЙ МАТЕРІАЛ}

Т.Л. Наливайко [1] розмежовує категорії «адаптації» та «адаптивності», поєднання яких є необхідною умовою їх взаємної реалізації. Тобто рівень адаптації до змін буде залежати від рівня його адаптивності як внутрішньої властивості системи. Під адаптацією запропоновано розуміти процес пристосування, зміни параметрів, складників і самої системи загалом, що відповідає баченню, висвітленому в роботі [2]. Зауважимо, що в науковому просторі $є$ класифікація адаптації, де іiі розрізняють за видами. У наукових колах виділяють кілька аспектів адаптації до змін та як властивості ефективної організації [3-5]: соціальна, науково-технічна, адміністративна адаптація. Так, Т. Хайман [5] розглядає адаптацію в розрізі властивостей ефективної організації: соціальна адаптація розуміється як «здатність враховувати зміни зовнішнього середовища та зміни внутрішнього соціального середовища при плануванні та прийнятті рішень», науково-технічна розуміється як сукупність вимог та використання досягнень НТП у сфері нових технологій, організації та методів управління, підготовки кадрів, адміністративна - як «відповідність організаційних форм та методів управління потребам процесу і системі управління, що характеризується стилем управління, автономністю підрозділів, ступенем делегування відповідальності».

Стосовно людини можна виділяти різноманітні види адаптації, адже цей процес пов'язаний із соціумом і людиною як соціальною істотою, відповідно, буде мати місце соціальна адаптація, яка охоплює широку сферу соціальних відносин. Праця як процес також відбувається в суспільстві, тому слід говорити про соціально-трудові відносини, в межах яких також відбуваються певні адаптаційні процеси. Відповідно, соціальна адаптація буде мати більш широке охоплення порівняно з адаптацією в процесі праці. Таке розуміння відповідає думці, що викладена в роботі [6], де 


\section{ЕКОНОМІКА ТА МЕНЕДЖМЕНТ № 1 2019}

адаптація трудова (розуміємо як таку, яка пов'язана із сферою праці) розглядається як один із головних видів соціальної адаптації.

Говорячи про адаптацію людини у сфері праці, сучасні дослідники використовують низку термінів, які трактуються неоднозначно, часто синонімічно, або, навпаки, протиставлені або підпорядковані один одному. Найчастіше зустрічаємо терміни «виробнича адаптація», «трудова адаптація», «професійна адаптація», «адаптація персоналу (працівників)».

Розгляд першої категорії «виробнича адаптація» варто здійснювати, по-перше, в протиставленні із «невиробничою (позавиробничою) адаптацією» (як різновиди адаптації за класифікаційною ознакою «за напрямами» [7]), а, по-друге, враховуючи етимологію слова «виробничий» (від виробництво).

У табл. 1 узагальнено розуміння виробничої та позавиробничої адаптацій, які зустрічаються у вітчизняній науковій думці.

Узагальнюючи визначення, що наведені в табл. 1 стосовно «виробничої адаптації», зазначимо як їх загальний характер $[6 ; 8 ; 11]$, який передбачає пристосування до організації (підприємства) взагалі, так і звужене розуміння - пристосування до нових виробничих умов $[6 ; 9 ; 10 ; 12-15]$. Саме тому необхідно звернутися до словникового тлумачення слова «виробничий» (від виробництво [17] - «процес, в ході якого люди, зв'язані між собою певними виробничими відносинами, створюють матеріальні блага, необхідні для суспільства»; «виробничі відносини [17] - зв'язки та відносини, що виникають між людьми в процесі суспільного виробництва матеріальних благ»). Таке визначення досить звужує межі адаптації на підприємстві лише до виробничих процесів зі створення матеріальних благ, а тому виникає питання щодо діяльності із продукування нематеріальних благ, яких у сучасній економіці багато. Окрім того, варто зауважити, що виробнича адаптація не може зводитися лише до адаптації працівника чи трудового колективу, адже у виробничому процесі задіяні й інші фактори - основні засоби, матеріали, енергія тощо. Відповідно, з таким розумінням виробнича адаптація ширша, ніж взаємодія працівника, його пристосування до навколишнього виробничого середовища.

Зважаючи на вищевикладене, доцільно розглянути тлумачення категорій «трудова адаптація» та «адаптація персоналу». Базуючись на розумінні персоналу підприємства, яке презентовано в роботі [18], будемо його розглядати як сукупність фізичних осіб, які мають трудові взаємовідносини із роботодавцем на основі трудового договору/контракту та кількісно представляють собою суму облікової чисельності штатних працівників підприємства та зовнішніх сумісників. Так, у роботі [4] адаптація персоналу

Таблиця 1. Узагальнення розуміння дефініцій виробничої та невиробничої адаптацій (узагальнено авторами)

\begin{tabular}{|c|c|}
\hline Вид адаптації & Визначення, джерело \\
\hline \multirow[t]{7}{*}{ Виробнича адаптація } & $\begin{array}{l}\text { «багатомірний процес, який включає в себе: пристосування працівника до умов праці та } \\
\text { колективу, змісту праці, соціального середовища; пізнання норм і традицій, прийнятих } \\
\text { на підприємстві; оволодіння професійними навичками та вміннями; формування деяких } \\
\text { професійно важливих якостей особистості; розвиток стійкого, позитивного ставлення } \\
\text { працівника до своєї професії» [8] }\end{array}$ \\
\hline & $\begin{array}{l}\text { «процес взаємодії працівника з навколишнім виробничим середовищем із метою } \\
\text { опанування нової для нього виробничої ситуації» }[9 ; 10]\end{array}$ \\
\hline & $\begin{array}{l}\text { «пристосування працівника до організації, яке грунтується на тому, що у співробітника } \\
\text { поступово з’являються нові професійні, соціальні, психологічні й економічні умови праці і, } \\
\text { відповідно, навички» [11] }\end{array}$ \\
\hline & $\begin{array}{l}\text { «процес взаємодії працівника з навколишнім виробничим середовищем підприємства } 3 \\
\text { метою опанування нової для працівника виробничої ситуації» [12-14]; «процес взаємодії } \\
\text { працівника та виробничого підрозділу підприємства із засвоєння інновацій у конкретній } \\
\text { ситуації» [12] }\end{array}$ \\
\hline & $\begin{array}{l}\text { «дія виробничих форм і методів організування праці, особливостей трудового колективу та } \\
\text { інших факторів на процес набуття новим працівником необхідних трудових навичок» [7] }\end{array}$ \\
\hline & $\begin{array}{l}\text { «двосторонній процес і результат перебудови функціонування організму та діяльності } \\
\text { працівника у відповідь на нові вимоги виробничого середовища, також його зміни в процесі } \\
\text { задоволення потреб працівника та інформаційний обмін між ними з метою забезпечення їх } \\
\text { взаємної ефективної діяльності та розвитку» [15] }\end{array}$ \\
\hline & $\begin{array}{l}\text { «включає такі види: професійну, психофізіологічну, соціально-психологічну, } \\
\text { організаційно-адміністративну, економічну, санітарно-гігієнічну та ін.» [16] }\end{array}$ \\
\hline \multirow{2}{*}{$\begin{array}{l}\text { Невиробнича } \\
\text { (позавиробнича) } \\
\text { адаптація }\end{array}$} & $\begin{array}{l}\text { «характерними її особливостями є вплив на працівника факторів його соціального буття, які } \\
\text { значною мірою зумовлюють його фізичний, емоційний стан» [7]. }\end{array}$ \\
\hline & $\begin{array}{l}\text { «включає побутову адаптацію і адаптацію позавиробничого спілкування з колегами, в тому } \\
\text { числі на корпоративних заходах» [16] }\end{array}$ \\
\hline
\end{tabular}


розглядається як «процес пристосування людини до нового середовища, що грунтується на поступовому включенні працівника до процесу виробництва у нових умовах». У цьому разі йдеться про пристосування безпосередньо працівника і наголошується на певному процесі. В дослідженні [19] адаптацію розглядають аналогічно - як пристосування до умов функціонування цього підприємства. При цьому наголошується на результативності, яка забезпечується взаємною узгодженістю інтересів працівника і підприємства. Таке розуміння корелює із широким розумінням «виробничої адаптації», що наведено в роботах $[7 ; 8 ; 11]$. Проведемо порівняння розглянутих категорій із категорією «трудова адаптація», узагальнення якої наведено в табл. 2.

3 аналізу визначень «трудової адаптації» в табл. 2 можемо зробити висновок про схожість тлумачень трудової, виробничої та адаптації: майже ідентична структура, процес пристосування людини; що є не зовсім коректним.

Тому необхідно розмежувати ці поняття. Для цього розкриємо сутнісне навантаження кожної із категорій через складники, які виділяються в їх межах.

Автором було узагальнено складники, які виділяються в межах розглянутих видів адаптації в табл. 3. 3 аналізу табл. 3 можемо зазначити, що виділення окремо соціальної адаптації в межах виробничої адаптації (табл. 3, дж. [15]) не є, на нашу думку, коректним, адже виробнича, як і трудова, $є$ проявом соціальної адаптації у сфері соціально-трудових та виробничих відносин. Також можна вважати синонімами соціально-психічну [6] та соціально-психологічну складові частини $[7 ; 8 ; 11 ; 12 ; 16]$, тому їх можна об'єднати (позначено підкресленням).

Таблиця 2. Узагальнення дефініцій «трудова адаптація» (узагальнено авторами)

\begin{tabular}{|c|c|}
\hline \multirow{5}{*}{ 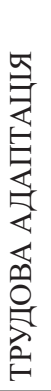 } & $\begin{array}{l}\text { «пристосування людини (групи людей) до змінних умов виробництва, ринку, трудового колективу } \\
\text { за допомогою різних соціальних засобів» [6] }\end{array}$ \\
\hline & $\begin{array}{l}\text { «взаємне пристосування працівника і підприємства, що грунтується на поступовій впрацьованості } \\
\text { працівника в нових професійних, соціальних і організаційно-економічних умовах праці» [20] }\end{array}$ \\
\hline & $\begin{array}{l}\text { «процес перебудови та пристосування особистісних, енергетичних, інформаційних, операційних } \\
\text { та інших структур і систем суб’єкта праці до особливостей трудової діяльності заради завдань найбільш } \\
\text { ефективної його саморегуляції на етапах професійного шляху» [21] }\end{array}$ \\
\hline & $\begin{array}{l}\text { «має складну структуру і являє собою єдність професійної, соціально-психологічної, } \\
\text { суспільно-організаційної, культурно-побутової та психофізичної адаптації» [22] }\end{array}$ \\
\hline & «соціальний процес освоєння особистістю нової трудової ситуації» [23] \\
\hline
\end{tabular}

Таблиця 3. Узагальнення структуризації адаптація працівників на підприємстві в розрізі компонент (узагальнено авторами)

\begin{tabular}{|c|c|c|c|c|c|c|c|c|c|c|c|c|c|c|c|c|c|}
\hline \multirow{3}{*}{ Складники адаптації } & \multicolumn{4}{|c|}{ Виробнича } & \multicolumn{4}{|c|}{ Позавиробнича } & \multicolumn{4}{|c|}{ Трудова } & \multicolumn{5}{|c|}{ Персоналу } \\
\hline & \multicolumn{17}{|c|}{ Джерела } \\
\hline & [7] & [16] & [15] & [12] & [11] & [8] & {$[16]$} & [7] & [6] & [20] & {$[22]$} & {$[24]$} & [23] & [25] & [26] & [27] & [28] \\
\hline професійна & + & + & + & + & + & + & - & - & + & + & + & + & + & + & + & + & + \\
\hline психофізіологічна & + & + & + & + & + & + & - & - & + & + & + & + & + & + & + & + & + \\
\hline соціально-психологічна & + & + & - & + & + & + & - & - & \pm & + & + & + & + & + & + & + & + \\
\hline $\begin{array}{l}\text { організаційно- } \\
\text { адміністративна }\end{array}$ & + & + & - & - & - & - & - & - & - & - & - & - & - & - & - & - & - \\
\hline економічна & + & + & - & - & - & - & - & - & - & - & - & - & - & - & - & - & - \\
\hline санітарно-гігієнічна & + & + & - & - & - & - & - & - & & - & - & - & - & - & - & - & - \\
\hline соціальна & - & - & + & - & - & - & - & - & - & - & - & - & - & - & - & - & - \\
\hline організаційна & - & - & + & - & + & - & - & - & + & + & - & - & + & + & + & + & + \\
\hline $\begin{array}{l}\text { у сфері дозвілля та } \\
\text { матеріально-побутовій } \\
\text { сфері }\end{array}$ & - & - & + & - & - & - & - & - & - & - & - & - & - & & - & - & - \\
\hline суспільноорганізаційна & - & - & - & - & - & + & - & - & - & - & + & - & + & - & & - & - \\
\hline культурнопобутова & - & - & - & - & - & + & - & - & - & - & + & & + & - & + & - & - \\
\hline соціально-психічна & - & - & - & - & - & - & - & - & \pm & - & - & - & - & - & - & - & - \\
\hline $\begin{array}{l}\text { позавиробничого } \\
\text { спілкування з колегами }\end{array}$ & - & - & - & - & - & - & + & + & - & - & - & - & - & - & - & - & - \\
\hline в період відпочинку & - & - & - & - & - & - & - & + & - & - & - & - & - & - & - & - & - \\
\hline $\begin{array}{l}\text { адаптація до побутових } \\
\text { умов }\end{array}$ & - & - & - & - & - & - & + & + & - & - & - & - & - & - & - & - & - \\
\hline соціаль & & & & & & & & & & & & & & + & & & \\
\hline
\end{tabular}




\section{ЕКОНОМІКА ТА МЕНЕДЖМЕНТ № 1 2019}

Як бачимо, спільними для всіх типів адаптації працівників є такі складники: професійна; психофізіологічна; соціально-психологічна, а також організаційна або організаційно-адміністративна. Водночас неможливо адаптувати працівника, не врахувавши економічний аспект діяльності, тому ми погоджуємося із думкою [7; 16] щодо доцільності виділення економічної адаптації. Зазначаємо, що адаптація, пов'язана із культурно-побутовою сферою, тобто сферою, яка не охоплює безпосередньо трудову діяльність працівників на підприємстві (позначено заливкою), присутня у виробничій $[8 ; 15]$ (особливо у позавиробничій [7; 16; 29] адаптаціі), а також у трудовій $[22 ; 23 ; 25]$ та адаптації персоналу [26]. Тому можна розцінювати виробничу та позавиробничу адаптації як складники трудової адаптації та адаптації персоналу. Водночас сам термін «виробничий» не $є$ досить коректним через свою обмеженість. Поділ на виробничу/позавиробничу доцільно трактувати як адаптація, що базується на трудовій діяльності, та адаптація, що не пов'язана із веденням трудової діяльності.

Водночас позавиробниче спілкування, яке широко розвивається в сучасних умовах, корпоративна культура, проведення вільного часу, дозвілля тощо в багатьох випадках суттєво визначають адаптацію працівників до трудової діяльності. Тому ці складники мають стати обов'язковою компонентою адаптації персоналу. Отже, сутність адаптації персоналу розкривається через ідентифікацію ії складових частин: професійної; психофізіологічної; соціально-психологічної, організаційної; економічної та культурно-побутової.

Необхідно розкрити сутнісне навантаження визначених складових частин адаптації персоналу на підприємстві, базуючись на морфологічному та структурно-логічному аналізі їх розуміння дослідниками, а також враховуючи фактори, які їх формують. У подальшому розподіл на складники або виділення видів адаптації за змістом є класифікаційною ознакою адаптації персоналу підприємства.

Перша складова частина - «професійна» - за ключовим словом розуміється як освоєння $[7 ; 12 ; 24 ; 21]$, коригування [6], оволодіння [22; 23], ознайомлення [26] - за змістовим навантаженням - професійних навичок та вмінь. Розуміння адаптації як «освоєння, оволодіння, ознайомлення», на нашу думку, не зовсім коректне, адже, незважаючи на вік та стаж працівника, він вже має певні професійні навички та вміння, тому на підприємстві відбувається уже удосконалення, коригування, пристосування професійних навичок та вмінь до специфіки конкретного підприємства. Слід зазначити деяку дуальність сприйняття адаптації персоналу на підприємстві: $з$ точку зору працівника та роботодавця. Тому, з боку працівника, професійна адаптація має розумітися як коригування професійних навичок та вмінь у відповідності до потреб даного робочого місця (підприємства) задля якісного здійснення професійної діяльності. 3 точки зору підприємства (погоджуємося з думкою [28]), професійна адаптація буде представляти собою «систему заходів, які сприяють професійному становленню працівника, формуванню в нього певних соціальних і професійних якостей, установок і потреб до активної творчої праці, досягненню вищого рівня професіоналізму» [28].

Аналізуючи другий вид трудової адаптації - психофізіологічну - зазначаємо її розуміння як «пристосування» $[6 ; 8 ; 11]$, «звикання» $[7 ; 26]$, «освоєння» [22; 23; 28], «адаптації» $[12 ; 24]$ до умов праці, режимів праці та відпочинку, фізіологічних та психологічних навантажень. За ключовим словом зазначаємо, що пристосування та адаптація можуть розглядатися як синоніми, звикання має більш пасивний характер, а освоєння умов праці чи певних психологічних навантажень не $є$ коректним. Варто погодитися, що умови праці, які мають досить широкий спектр охоплення (санітарно-гігієнічні, ергономічні, техніко-технологічні тощо) та визначають рівень психофізіологічного навантаження, є прямими факторами впливу на діяльність працівника і будуть визначати його психофізіологічну адаптацію. Водночас режим праці та відпочинку є елементом організаційного процесу, але буде безпосередньо діяти на психофізіологічну адаптацію. Тому під психофізіологічною адаптацією пропонуємо розуміти пристосування працівників до конкретних умов та режимів праці й відпочинку та рівня психофізіологічного навантаження, які його створюють.

Соціально-психологічна складова частина за ключовими словами базується на «пристосуванні» [6; 8; 11], «входженні» [7; 26], «вливанні» [28], «освоєнні» [26; 22] та «адаптації» [12; 24] працівника до нового соціуму, традицій, неписаних норм, стилю роботи керівників, особистих та міжособистісних відносин, організаційної та корпоративної культури. Знову ж таки, розглядаючи пристосування та адаптацію і входження та вливання як синоніми, більшість науковців вважають цей тип адаптації пристосуванням до традицій, неписаних традицій, стилю тощо. Отже, під соціально-психологічною адаптацією пропонуємо розуміти пристосування працівника до конкретного соціуму, його традицій, неписаних норм та правил, стилю керівництва, міжособистісних та особистісних відносин, організаційної (корпоративної) культури.

Остання складова частина має організаційний характер та розуміється у двох аспектах: 1) опанування ролі, місця та статусу [6; 7] в організаційній структурі підприємства, структурного підрозділу; 2) засвоєння $[8 ; 11 ; 22 ; 2 ; 26]$ організаційної структури та організаційно-управлінських процесів на підприємстві. Авторське бачення організаційної компоненти базується на більш активному іiі сприйнятті як опанування, 


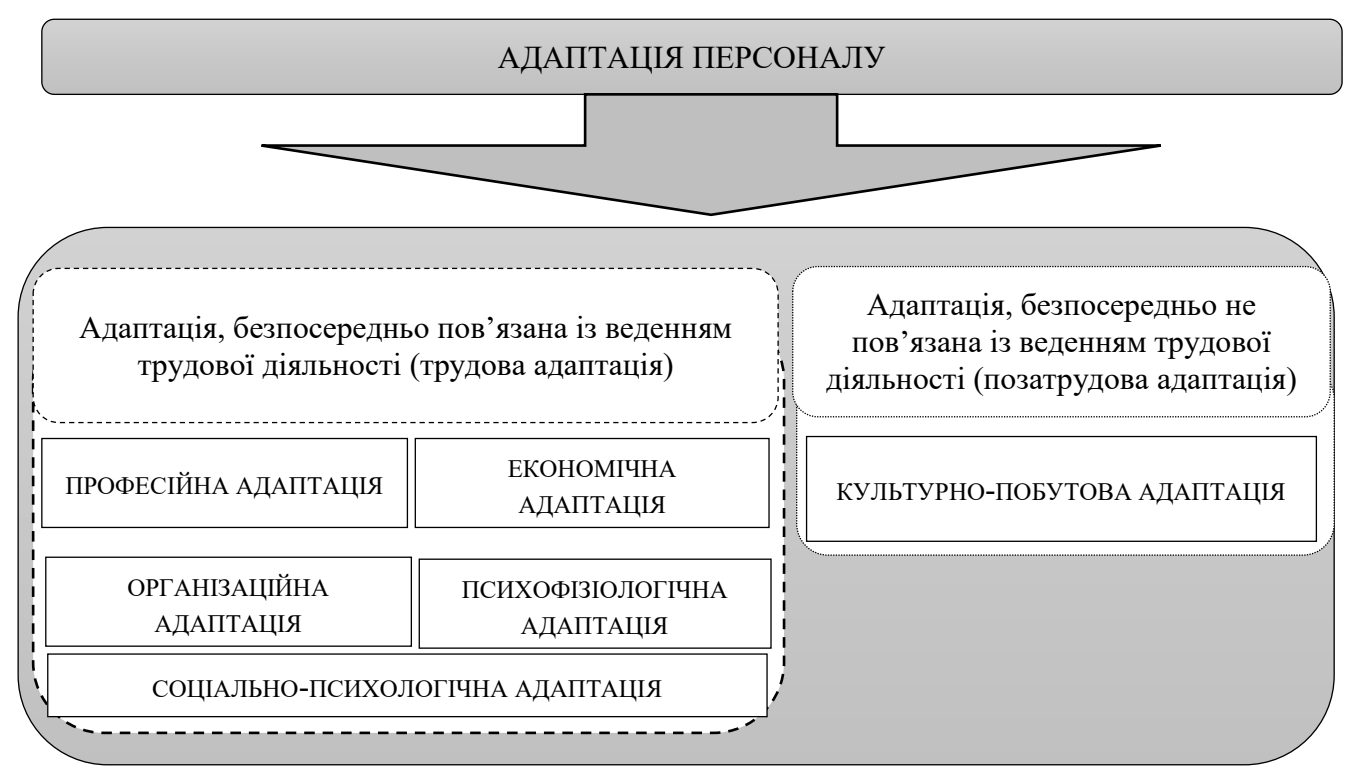

Рис. 1. Складники адаптації персоналу на підприємстві (розроблено авторами)

визначення ролі, місця та статусу в організаційній структурі, що передбачає як засвоєння наявного організаційно-управлінського стану, так і вплив на цей стан працівника.

Ще одну компоненту - економічну, незважаючи на iii незначну популярність [7; 16], пропонується виокремити в трудовій адаптації персоналу. Виходячи з іiі розуміння як «пристосування працівника до рівня заробітної плати і матеріального стимулювання, які відповідають робочому місцю, посаді, рівню його кваліфікації» [7], будемо вважати іiі необхідною умовою ведення якісної трудової діяльності, адже в попередніх складниках економічний аспект не враховано. Також складовою частиною, яка визначає адаптацію персоналу, але безпосередньо не пов'язана із трудовою діяльністю є культурно-побутова адаптація $[8 ; 22 ; 23 ; 26]$ або адаптація до позавиробничих умов взаємодії, яка представлена різними складниками $[7 ; 16]$ (табл. 3). У першому випадку [8; 22; 23; 26] вона передбачає освоєння працівником в організації особливостей побуту і традицій проведення вільного часу, що відповідає адаптації в період відпочинку та позавиробничого (позатрудової діяльності) спілкування, але не передбачає адаптацію до побутових умов, як це передбачено [7; 16]. Побутове пристосування має на увазі «забезпечення працівника нормальними побутовими умовами (житло, транспортну логістику, харчування, влаштування дітей в дитячі садки, медичне обслуговування, тощо) [7; 16]. Тому пропонується культурно-побутову адаптацію розглядати як пристосування працівника до особливостей проведення вільного часу, культурного дозвілля та побутових умов.

Відповідно, можемо запропонувати авторське бачення структурування та співвіднесення видів адаптації персоналу (працівників) на підприємстві (рис. 1).

Саме визначені складники будуть розкривати сутнісне навантаження адаптації персоналу на підприємствах в сучасних умовах.

\section{ВИСНОВКИ}

У дослідженні було проаналізовано, впорядковано та розмежовано категорії, які описують адаптацію працівника на підприємстві: «виробнича адаптація», «невиробнича адаптація», «трудова адаптація» та «адаптація персоналу». Визначено, що використання терміна «виробнича адаптація» має обмежений i еволюційно недоцільний характер у сучасних умовах господарювання, тому більш справедливим $є$ виділення в межах адаптації персоналу адаптації, яка безпосередньо пов'язана із веденням трудової діяльності (трудова адаптація), та адаптації, яка безпосередньо не пов'язана із веденням трудової діяльності (позатрудова адаптація).

Визначено, що сутнісне навантаження адаптації персоналу доцільно розкривати через виділення окремих компонент (видів адаптації персоналу за змістовою класифікаційною ознакою), до яких зараховано професійну, психофізіологічну, соціально-психологічну, організаційну, економічну та культурно-побутову. Відповідно, надано авторське переосмислення сутності вказаних видів адаптації.

До подальших напрямів досліджень варто зарахувати вивчення та розширення класифікації адаптації персоналу, а також обгрунтування факторів, що визначають види адаптації, і методичного інструментарію її здійснення. 


\section{ЕКОНОМІКА ТА МЕНЕДЖМЕНТ № 1-2019}

\section{REFERENCES}

[1] Nalyvaiko, T.(2019),Identyfikatsiiaponiatiino-katehorialnoho aparatuadaptyvnohoupravlinnia.Ekonomika ta derzhava,[Identification of conceptual and categorical apparatus adaptive management]. vol. 9, pp. 95-102. DOI: 10.32702/2306-6806.2019.9.95

[2] Yachmen'ova, V. M., Osmanova, Z. O. (2010), [The essence of the concepts of adaptation and adaptability]. Retrieved from: http://ena. lp.edu.ua:8080/bitstream/ntb/18798/1/72-346-353.pdf (last accessed 17.08.19).

[3] Kulyk, N. M., Sokolenko, T.M. (2013), Tekhnolohiia adaptatsii u systemi upravlinnia pidpryiemstvom. [Adaptation technology in enterprise management system]. Ekonomichnyi analiz, Vol. 14, № 3, pp. 96-100.

[4] Khemel, G., Prakhalad, G., Tomas, D. O’Nil (2005) Strategicheskaya gibkost [Strategic flexibility]. Spb. Piter. 384 p.

[5] Herasymova, O. L., Podolianu, M. V., Chachkova, A. V. (2017) Adaptatsiia pidpryiemstva do zmin u zovnishnomu seredovyshchi yak zasib zabezpechennia yoho ekonomichnoi bezpeky [Adaptation of the enterprise to changes in the external environment as a means of ensuring its economic security]. Infrastruktura rynku. Vyp. 6. pp. 141-146

[6] Tulenkov, M. V. (2019), Adaptatsiia trudova. Velyka ukrainska entsyklopediia. [Labor adaptation. Great Ukrainian Encyclopedia] Retrieved from: http://vue.gov.ua/Adaptation of labor. Great Ukrainian Encyclopedia (last accessed: 6.10.2019).

[7] Orhanizatsiia vyrobnychoi i sotsialnoi adaptatsii robitnykiv [Organization of production and social adaptation of workers]. Retrieved from: https://studopedia.su/1_43015_organizatsiya-virobnichoi-i-sotsialnoi-adaptatsii-robitnikiv.html (last accessed: 6.10.2019)

[8] Kondryukova, V. V. (2011), Adaptatsiia do profesiinoi diialnosti: sotsialno-psykholohichnyi aspekt [Adaptation to professional activity: socio-psychological aspect]. Legal Bulletin of KROK University. Vol. 9. P. 139-143. Retrieved from: http://nbuv.gov.ua/ UJRN/Pvuk_2011_9_21.

[9] Baklyts'kyi, I. O. (2008), Psykholohiia pratsi [Labor Psychology]: Textbook. 2nd ed. Kyiv, 655 p.

[10] Lukashevich, N. P. (1989), Proizvodstvennaya adaptatsiya kak element trudovoy karyery rabotnika [Production adaptation as an element of employee's career]. Kyiv, $25 \mathrm{p}$.

[11] Pererva, A. (2018), Adaptatsiia yak prystosuvannia pratsivnyka do umov pratsi v derzhavnomu orhani [Adaptation as an adaptation of an employee to working conditions in public authority]. Civil servant. № 7. Retrieved from: https://i.factor.ua/ukr/journals/ds/2018/ july/issue-7/article-37777.html

[12] Moroz, L. I. Kontsovs'ka, S. Ya. Vyrobnycha adaptatsiia personalu pidpryiemstva v suchasnykh umovakh [Production adaptation of the personnel of the enterprise in modern conditions]. Retrieved from: https://sworld.com.ua/konfer38/435.pdf

[13] Savelyeva, V. S., Eskov, O. L., Vakulenko, V. M. (2012), Orhanizatsiina povedinka [Organizational behavior]. Kyiv, 240 p.

[14] Voronkova, V. G. (2004), Kadrovyi menedzhment [Personnel management]. Kyiv, 192 p.

[15] Savchenko, V. A. (2002), Upravlinnia rozvytkom personalu [Human Resource Management]. Kyiv, 351 p.

[16] Uprvleniye personalom [Personnel Management]. Retrieved from: https://stud.com.ua/59114/menedzhment/virobnicha_adaptatsiya

[17] Akademichnyi tlumachnyi slovnyk (1970-1980). [Academic Interpretative Dictionary (1970-1980)] Retrieved from: http://sum. in.ua/s/ljudyna

[18] Smachylo, V. V., Nalyvaiko, T. L. (2019). Identyfikatsiia sotsialno-ekonomichnoi katehorii "personal pidpryiemstva". [Identification of socio-economic category “enterprise staff”]. Bulletin ZhDTU. № 3 (89).

[19] Lutsyk, T. R. (2006), "Management of industrial enterprise restructuring processes (on the example of the shoe industry)", Ph.D. Thesis, Economics, organization and management of enterprises, Kyiv National University of Technology and Design, Kyiv, Ukraine.

[20] Balabanova, L. V., Sardak, O. V. (2011), Upravlinnia personalom [HR management]. Kyiv, 468 p.

[21] Tolkov, O. S. (2015), Psykholohichni osoblyvosti adaptatsii do trudovoi diialnosti medychnykh pratsivnykiv [Psychological peculiarities of adaptation to the labor activity of medical workers]. Bulletin of Chernihiv National Pedagogical University. Series: Psychological Sciences. Vol. 128. P. 253-256. Retrieved from: http://nbuv.gov.ua/UJRN/VchdpuPH_2015_128_58.

[22] Adamchuk, V. V., Romashov, O. V., Sorokina, M. E. (2000). Ekonomika i sotsiolohiia pratsi [Economics and sociology of labor]. Moscow, $407 \mathrm{p}$.

[23] Pol'ova, N. M., Kulyk, Ya. O. (2012), Upravlinnia adaptatsiieiu novykh pratsivnykiv [Managing the adaptation of new employees]. Investment: practice and experience. № 12. P. 47-50.

[24] Nikiforenko, V. G. (2013), Upravlinnia personalom [HR management]. Odesa, 275 p.

[25] Alekseeva, K. (2007), Rabochaya kost v gorle: o trudoustroystve vypusknikov professionalnykh uchilishch i tekhnikumov [Working bone in the throat: on the employment of graduates of vocational schools and technical schools]. Professional. Vol. 5. P. 19.

[26] Maksymyuk, G. M. (2016), Adaptatsiia personalu: analiz pohliadiv vitchyznianykh ta zakordonnykh naukovtsiv [Personnel adaptation: analysis of the views of domestic and foreign scientists]. Scientific Bulletin of Kherson State University. Series: Economic Sciences. Issue 20. Part 1. P. 122-125

[27] Vasylichev, D. V., Miroshnichenko, V. A. (2014), Orhanizatsiia protsesu adaptatsii personalu na pidpryiemstvi. [Organization of personnel adaptation process at the enterprise]. Economics and management organization. Vol. 3-4. P. 44-50.

[28] Get'man, O. O., Red'ko, V. A. (2017), Osoblyvosti rozroblennia prohram adaptatsii personalu na pidpryiemstvakh kharchovoi promyslovosti [Features of development of programs of adaptation of the personnel at the enterprises of the food-processing industry]. Economy and society. Vol. 13. P. 969-975.

[29] Strelchenko, N. M., Herneshii, V. V. (2011) Personal v transnatsionalnykh finansovykh strukturakh za umov hlobalizatsii informatsiinoi epokhy. [Staff in transnational financial institutions in the context of the globalization of the information age.] Ukraine's Development Strategy. №4. p. 2. pp. 226-229. 


\section{СПИСОК ВИКОРИСТАНОЇ ЛІТЕРАТУРИ}

[1] Наливайко, Т. Л. (2019) Ідентифікація понятійно-категоріального апарату адаптивного управління. Економіка та держсава. № 9. С. 95-102.

[2] Ячменьова, В. М., Османова, 3. О. (2010) Сутність понять «адаптація» та «адаптивність». URL: http://ena.lp.edu. ua:8080/bitstream/ntb/18798/1/72-346-353.pdf (дата звернення 17.08.2019).

[3] Кулик, Н. М., Соколенко, Т.М. (2013) Технологія адаптації у системі управління підприємством. Економічний аналіз. Том 14. № 3. С. $96-100$.

[4] Хэмэл, Г., Прахалад, Г. Томас, Д. О’Нил (2005) Стратегическая гибкость. Санкт-Петербург : Питер.

[5] Герасимова, О. Л., Подоляну, М. В., Чачкова, А. В. (2017) Адаптація підприємства до змін у зовнішньому середовищі як засіб забезпечення його економічної безпеки Інфраструктура ринку. Вип. 6. С. 141-146

[6] Туленков, M. В. Адаптація трудова. Велика українська енциклопедія. URL: http://vue.gov.ua/Адаптація трудова (дата звернення: 06.10.2019).

[7] Організація виробничої і соціальної адаптації робітників. URL: https://studopedia.su/1_43015_organizatsiyavirobnichoi-i-sotsialnoi-adaptatsii-robitnikiv.html (дата звернення: 6.10.2019)

[8] Кондрюкова, В. В. (2011) Адаптація до професійної діяльності: соціально-психологічний аспект. Правничий вісник Університету «КРОК». Вип. 9. С. 139-143.

[9] Баклицький, І. О. (2008) Психологія праці. Київ : Знання. 655 с.

[10] Лукашевич, Н. П. (1989) Производственная адаптация как элемент трудовой карьеры работника. Киев : Знание. $25 \mathrm{c}$.

[11] Перерва, А. (2018) Адаптація як пристосування працівника до умов праці в державному органі. Держслужбовець. № 7. URL: https://i.factor.ua/ukr/journals/ds/2018/july/issue-7/article-37777.html

[12] Мороз, Л. І., Концовська, С. Я. Виробнича адаптація персоналу підприємства в сучасних умовах. URL: https://sworld.com.ua/konfer38/435.pdf

[13] Савельєва В. С., Єськов О. Л., Вакуленко В. М. (2012) Організаційна поведінка. Київ: «Центр учбової літератури». $240 \mathrm{c.}$

[14] Воронкова, В. Г. (2004) Кадровий менеджмент. Київ : «Професіонал». 192 с.

[15] Савченко, В. А. (2002) Управління розвитком персоналу. Київ : КНЕУ. 351 с.

[16] Управление персоналом. URL: https://stud.com.ua/59114/menedzhment/virobnicha_adaptatsiya

[17] Академічний тлумачний словник (1970-1980). URL: http://sum.in.ua/s/ljudyna

[18] Смачило, В. В., Наливайко, Т. Л. (2019) Ідентифікація соціально-економічної категорії «персонал підприємства». Вісник ЖДТУ. № 3 (89). С. 47-56.

[19] Луцик, Т. Р. (2006) Управління процесами реструктуризації промислового підприємства (на прикладі взуттєвої галузі) : автореф. дис. ... канд. екон. наук : 08.06.01 / Київський національний ун-т технологій та дизайну. Київ, 19 с.

[20] Балабанова, Л. В., Сардак, О. В. (2011) Управління персоналом. Київ : Центр учбової літератури, 468 с.

[21] Толков, О. С. (2015) Психологічні особливості адаптації до трудової діяльності медичних працівників. Вісник Чернігівського національного педагогічного університету. Серія: Психологічні науки. Вип. 128. С. $253-256$.

[22] Адамчук, В. В., Ромашов, О. В., Сорокіна М. Е. (2000) Економіка і соціологія праці. М.: ЮНИТИ. 407 с.

[23] Польова, Н. М., Кулик, Я. О. (2012) Управління адаптацією нових працівників. Інвестиції: практика та досвід. № 12. C. $47-50$.

[24] Никифоренко, В. Г. (2013) Управління персоналом. Одеса : Атлант. 275 с.

[25] Алексеева, К. (2007) Рабочая кость в горле: о трудоустройстве выпускников профессиональных училищ и техникумов. Профессионал. Вып. 5. С. 19.

[26] Максимюк, Г. М. (2016) Адаптація персоналу: аналіз поглядів вітчизняних та закордонних науковців. Науковий вісник Херсонського державного університету. Серія: Економічні науки. Вип. 20. Ч. 1. С. 122-125.

[27] Василичев, Д. В., Мирошниченко, В. А. (2014) Організація процесу адаптації персоналу на підприємстві. Економіка і організація управління. Вип. 3-4. С. 44-50.

[28] Гетьман, О. О., Редько, В. А. (2017) Особливості розроблення програм адаптації персоналу на підприємствах харчової промисловості. Економіка і суспільство. Вип. 13. С. 969-975.

[29] Стрельченко, Н.М., Гернешій, В.В. (2011) Персонал в транснаціональних фінансових структурах за умов глобалізації інформаційної епохи. Стратегія розвитку України. № 4. Т. 2. С. 226-229. 